\title{
KARAKTERISTIK FISIKO-KIMIA DAN SENSORI VELVA PEPAYA (Carica papaya L.) DENGAN PEMANIS MADU
}

\author{
PHYSICOCHEMICAL CHARACTERISTIC AND SENSORY VELVA PAPAYA ( Carica \\ papaya L.) WITH HONEY SWEETENER
}

\author{
Suci Rahmawati ${ }^{* 1}$, Edhi Nurhartadi ${ }^{1)}$, Dwi Ishartani ${ }^{1)}$ \\ ${ }^{I}$ Program Studi Ilmu dan Teknologi Pangan \\ Email: suci_rahmawati1990@yahoo.com
}

\begin{abstract}
The purpose of this study was to know the influence of variation the concentration of honey purpose as supplementary as sucrose to physical characteristic, chemical, and sensory velva papaya. This study used a Completely Randomized Design (CRD) with one factor, honey concentration. Concentration addition of honey in velva papaya starting form 5-15\%. There was twice repetitions of sample and three times for analysis repetition. Data showed of physical, chemical and sensory characteristic were analyzed using One Way ANOVA at $\alpha=$ 0,05 level and if there is significant differences followed by Duncan Multiple Range Test (DMRT) at $\alpha=0,05$. For the data that abtained from testing the intensity of sweetness, if there is significant differences followed by Tukey test. The results showed that honey as a sweetener increased dietary fiber, vitamin $C, \beta$-carotene, antioxidants activity, melting point total soluble solid and decreased moisture content and overrun. Using the honey sweetener can affect significantly the sensory characteristics that made lower the favor level of panelist on the parameters of color, flavor, texture, and overall of velva pepaya. Intensity content (scoring test) known that velva papaya with 5\% concentration honey had less sweet than velva papaya with $20 \%$ sucrose, $10 \%$ concentration honey has same level with velva papaya with $20 \%$ sucrose and $15 \%$ concentration honey was than velva papaya with $20 \%$ sucrose.
\end{abstract}

Keywords: honey, sucrose, velva papaya

\section{ABSTRAK}

Tujuan dari penelitian ini adalah untuk mengetahui pengaruh variasi konsentrasi madu sebagai pengganti sukrosa terhadap karakteristik fisik, kimia, dan sensori velva pepaya. Penelitian ini menggunakan pola Rancangan Acak Lengkap (RAL) dengan satu faktor yaitu konsentrasi pemanis madu. Konsentrasi pemanis madu yang digunakan 5-15\%. Dilakukan pengulangan sampel sebanyak dua kali dan tiga kali pengulangan analisa. Data yang diperoleh pada pengujian fisik, kimia, sensori dianalisis menggunakan one way ANOVA pada tingkat $\alpha=0,05$. Jika terdapat perbedaan nyata, maka dilanjutkan dengan uji Duncan Multiple Range Test (DMRT) pada $\alpha=0,05$. Untuk data yang diperoleh dari uji Intensitas Tingkat Kemanisan, jika ada perbedaan nyata dilanjutkan dengan uji Tukey. Hasil penelitian yang diperoleh penggunaan pemanis madu meningkatkan serat pangan, vitamin $\mathrm{C}, \beta$-karoten, aktivitas antioksidan, daya leleh, dan total padatan terlarut, serta menurunkan kadar air dan overrun velva pepaya yang dihasilkan. Penggunaan pemanis madu berpengaruh nyata terhadap karakteristik sensori yaitu menurunkan tingkat kesukaan panelis pada parameter warna, rasa, aroma, tekstur, dan overall velva pepaya. Uji intensitas tingkat kemanisan diketahui bahwa velva pepaya dengan $5 \%$ pemanis madu memiliki tingkat kemanisan lebih rendah dari velva pepaya dengan $20 \%$ pemanis sukrosa, velva pepaya dengan $10 \%$ pemanis madu memiliki tingkat kemanisan sama dengan velva pepaya dengan $20 \%$ pemanis sukrosa dan velva pepaya dengan $15 \%$ pemanis madu memiliki tingkat kemanisan lebih tinggi dari velva pepaya dengan $20 \%$ pemanis sukrosa.

Kata kunci: madu, sukrosa, velva papaya

\section{PENDAHULUAN}

Pepaya merupakan tanaman tropis yang bernilai ekonomis tinggi. Buah pepaya juga termasuk salah satu hasil utama tanaman yang banyak digemari oleh masyarakat. Baik buah pepaya yang masih muda, mengkal, maupun masak (matang). Buah pepaya mengandung berbagai jenis vitamin yang bermanfaat untuk mempertahankan kesehatan dan harga yang relatif mudah dijangkau.
Buah pepaya dapat dikonsumsi langsung sebagai buah segar atau dibuat berbagai jenis sajian, seperti rujak, jus, minuman penyegar, campuran agar, dibuat selai, atau manisan (Ihsan dan Anang, 2010).

Buah pepaya mudah didapatkan kapan saja yang kita inginkan atau dapat dikatakan bahwa buah pepaya tidak mengenal musim atau dapat tumbuh disepanjang musim. Menurut Dinas Pertanian Tanaman Pangan dan Hortikultura Provinsi Jawa 
Tengah, produksi buah pepaya di Kabupaten Boyolali pada tahun 2011 sebesar 99.760 ton. Buah pepaya digemari oleh banyak masyarakat karena memiliki rasa yang manis, segar, dan kaya akan vitamin khususnya vitamin A dan vitamin C. Wills, et al (1989) dalam Dominica (1998) mengatakan bahwa pepaya merupakan produk hortikultura yang mempunyai sifat mudah rusak, dan diperkirakan kehilangan setelah proses pemanenan sebesar 25-80\% dari buah segar dan sayuran. Nilai tambah pengolahan buah pepaya dapat dikatakan masih terbatas, oleh karena itu perlu dilakukan lagi pengolahan buah pepaya yang dapat disukai oleh konsumen. Salah satu alternatif variasi pengolahan buah pepaya yaitu dapat diolah menjadi velva buah. Velva buah termasuk jenis makanan beku pencuci mulut sejenis es krim atau disebut dengan frozen dessert.

Produk-produk frozen dessert seperti es krim dan lainnya banyak disukai konsumen karena memiliki rasa yang manis dan menyegarkan. Perkembangan bisnis produk frozen dessert seperti es krim dapat dikatakan berkembang pesat terlihat dengan munculnya berbagai jenis merk es krim di pasaran. Selain es krim kini berkembang produk beku lainnya yaitu velva buah. Velva buah merupakan produk beku yang memiliki testur seperti es krim yang terbuat dari puree (hancuran) buah dengan campuran sukrosa. Produk velva ini memiliki keunggulan yang lebih dibandingkan dengan es krim karena tidak menggunakan lemak susu sebagai bahan pencampurnya sehingga kadar lemak yang terkandung dalam velva buah cukup rendah. Tidak hanya itu, produk velva lebih memiliki kandungan serat dan vitamin lebih yang berasal dari buah sebagai bahan baku utama pembuatan velva. Aroma dan citarasa yang khas dari buah sebagai bahan baku menjadikan produk velva memiliki daya tarik dan ciri khas yang berbeda dengan produk sejenis. Hal tersebut dapat dijadikan peluang untuk bisnis pangan dengan produk velva yang menyehatkan, relatif murah serta bercitarasa lezat dan dapat diterima oleh konsumen.

Pada umumnya pembuatan velva buah menggunakan sukrosa sebagai pemanis. Selain sebagai pemanis, penggunaan sukrosa dalam pembuatan makanan beku dapat memperbaiki body dan tekstur serta dapat mencegah pembentukan kristal es yang besar selama pembekuan (Kartika, 2010). Namun demikian jumlah kalori sukrosa yang tinggi perlu diperhatikan bagi konsumen yang diet rendah kalori. Untuk mengatasi hal tersebut maka pembuatan velva pepaya kali ini menggunakan madu sebagai pemanis pengganti sukrosa, karena diketahui bahwa madu memiliki kalori yang lebih rendah dibandingkan dengan sukrosa. Madu adalah cairan manis yang berasal dari nektar tanaman yang diproses oleh lebah pekerja menjadi madu dan tersimpan dalam sel-sel sarang lebah. Berbagai kelebihan madu sebagai makanan bernutrient tinggi sudah diketahui sejak zaman dahulu. Salah satu keunggulan madu dari pada gula pasir yaitu madu dapat langsung diproses tubuh menjadi energi, sedangkan gula pasir harus diproses terlebih dahulu oleh enzim pencernaan untuk dijadikan energi bagi tubuh. Selain itu madu memiliki beberapa kandungan yang tidak terdapat pada gula pasir, seperti protein, serat, vitamin B6, vitamin $\mathrm{C}$, riboflavin, pantotenat, asam folat, kalsium, fosfor, kalium, $\mathrm{Fe}$, dan Zn. Dari beberapa keunggulan tersebut dapat dikatakan madu memiliki kandungan yang lebih lengkap dan lebih sehat daripada gula pasir (Putriwindani, 2011).

Madu pada umumnya mengandung dua gula utama yaitu fruktosa dan glukosa. Fruktosa adalah gula sederhana dengan tingkat kemanisan yang paling tinggi namun kalorinya rendah. Menurut Prahastuti (2011), fruktosa digunakan sebagai pemanis oleh industri makanan karena mempunyai rasa paling manis diantara jenis karbohidrat lainnya, bahkan 1,7 kali lebih manis bila dibandingkan sukrosa.

Menurut Parwata dkk (2010), madu mengandung vitamin A, B1, B2, B3, B5, B6, $\mathrm{C}, \mathrm{D}, \mathrm{E}, \mathrm{K}$, beta karoten, flavonoid, asam fenolik, asam urat dan asam nikotinat. Di dalam madu juga terdapat kandungan mineral dan garam atau zat lain seperti zat besi, sulfur, magnesium, kalsium, kalium, khlor, natrium, fosfor dan sodium serta antibiotika dan enzim pencernaan. Selain kandungan madu tersebut di dalam madu juga terdapat 
senyawa yang berfungsi sebagai antioksidan. Antioksidan yang terkandung dalam madu adalah beta karoten, karena beta karoten mempunyai kemampuan yang handal dalam meredam radikal bebas. Selain itu madu dapat meningkatkan nilai gizi, berdasarkan hasil penelitian Aji (2011), penambahan madu yang ditambahkan pada minuman fungsional sari buah naga putih (Hylocereus undatus) dapat meningkatkan kandungan vitamin $\mathrm{C}$ dalam minuman yang dihasilkan. Kadar vitamin $\mathrm{C}$ pada minuman fungsional sari buah naga putih (Hylocereus undatus) sebesar $11,22 \%$ setelah ditambahkan madu kadar vitamin $\mathrm{C}$ meningkat menjadi sebesar $14,51 \%$. Semakin tinggi jumlah konsentrasi madu yang ditambahkan maka semakin tinggi pula kadar vitamin $\mathrm{C}$ minuman fungsional sari buah naga putih (Hylocereus undatus) yang dihasilkan. Selain kadar vitamin $\mathrm{C}$ yang meningkat, penambahan madu juga meningkatkan kadar antioksidan pada minuman fungsional sari buah naga putih (Hylocereus undatus) yang dihasilkan.

Seperti yang telah dikatakan sebelumnya madu memiliki kandungan gizi dan fungsional yang lebih lengkap dibandingkan gula (sukrosa). Penggantian madu sebagai pemanis dalam pembuatan velva pepaya dapat mempengaruhi karakteristik fisiko-kimia dan sensori velva pepaya. Oleh karena itu, perlu dilakukan penelitian penggunaan madu sebagai pengganti sukrosa dalam pembuatan velva pepaya.

\section{METODE PENELITIAN}

\section{Bahan dan Alat}

Bahan yang digunakan dalam pembuatan velva pepaya yang utama yaitu pepaya bangkok dari daerah Boyolali. Gula (sukrosa) diperoleh dari Pasar Gede di Surakarta. CMC dan asam sitrat diperoleh dari toko bahan kimia (SABA) di Surakarta, serta Gum arab yang didapatkan dari Toko Multi Kimia Raya Semarang yang diproduksi oleh PT. Indesso Niagatama, Purwokerto Jawa Tengah. Madu kelengkeng diperoleh dari Perhutani Solo. Sedangkan bahan-bahan kimia yang digunakan untuk analisis sifat kimia adalah aquades, $\mathrm{NaOH} 0,1 \mathrm{~N}$, indikator fenolftalein (PP) $\mathrm{pH}$ 8-10, indikator pati, larutan iod $0,01 \mathrm{~N}$, kloroform etanol (2:1), $\mathrm{NaCl} 0,38 \%$, aseton, heksan, etanol, petroleum eter, methanol, $\mathrm{Na}_{2} \mathrm{SO}_{4}$, buffer fosfat, termamyl, amyloglukosidase, dan larutan DPPH (1,1-Diphenyl-2picrylhydrazyl).

Alat yang digunakan dalam pembuatan velva pepaya antara lain blender (Cosmos), mixer (Philips HR 1530), freezer (Madona), gelas krus, gelas beker (Pyrex), tabung reaksi (Pyrex), labu takar $100 \mathrm{ml}$. erlenmeyer 250 ml, timbangan analitik (Ohaus Adventurer), oven (Memmert), water bath, refraktrometer (Atago), spektrofotometer UV- Vis (Shimadzu), Stopwatch.

\section{Tahapan Penelitian}

\section{Penelitian pendahuluan}

Penelitian pendahuluan ini mengikuti formulasi penelitian sebelumnya yaitu Eswandari (2012) dengan rasio perbandingan air dan buah 1:1 dan konsentrasi penggunaan gula sebesar $20 \%$. Pada penelitian pendahuluan ini juga dilakukan penentuan formulasi penambahan madu.

2. Penelitian utama

Penelitian utama adalah pembuatan velva pepaya dengan pemanis madu kemudian dilanjutkan dengan analisis organoleptik dan sifat fisik. Proses pembuatan velva pepaya dengan penambahan madu dimulai dengan persiapan bahan baku. Buah pepaya dikupas, diambil daging buahnya, dibuang biji dan bagian yang tidak dapat dimakan, kemudian dicuci dan dipotongpotong. Potongan-potongan daging buah pepaya kemudian diblansir dengan cara dikukus pada suhu $90^{\circ} \mathrm{C}$ selama 5 menit. Potongan buah pepaya selanjutnya dihancurkan dengan blender sampai menjadi bubur buah (puree). Gula pasir (sukrosa) ditambahkan ke dalam puree dengan presentase $20 \%$ dari total adonan. Sedangkan untuk ketiga perlakuan lainnya antara lain penambahan pemanis madu 5\% (F1) dari total adnona, $10 \%$ pemanis madu (F2) dari total adonan, dan $15 \%$ pemanis madu (F3) dari total adonan. Setelah itu ditambahkan air matang (1 bagian) kedalam puree, kemudian dihaluskan 
kembali selama 3 menit hingga gula menjadi larut.

Bahan penstabil dilarutkan dengan sedikit air dan dipanaskan sampai terlihat jernih. Larutan ditambahkan sedikit demi sedikit ke dalam puree kemudian diaduk kembali. Bahan penstabil yang digunakan pada penelitian ini adalah CMC dan Gum arab $0,3 \%$ Tingkat konsentrasi ini dipilih berdasarkan hasil penelitian Eswandari (2012) tentang velva pepaya dengan kombinasi penstabil yang menunjukkan kesukaan tertinggi panelis pada produk dengan penambahan CMC dan gum arab pada konsentrasi tersebut.

Penambahan selanjutnya adalah asam sitrat $0,1 \%$ dan jeruk nipis $0,8 \%$ dari berat puree yang telah dilarutkan dalam air. Adonan diaduk selama kurang lebih 15 menit dengan menggunakan mixer kecepatan rendah sampai merata. Adonan yang sudah tercampur homogen selanjutnya dibekukan di dalam freezer bersuhu $-12^{\circ} \mathrm{C}$ selama $8-12$ jam. Tahap selanjutnya adalah pengadukan kembali dengan menggunakan mixer selama 15 menit untuk menghasilkan tekstur velva. Tahap terakhir pengerasan velva dalam freezer dengan sihu $-20^{\circ} \mathrm{C}$ selama 3 jam.

Analisis yang dilakukan pada velva pepaya dengan pemanis madu sebagai pengganti pemanis meliputi analisis sensori (Uji kesukaan dengan metode scoring dan uji pembedaan intensitas tingkat kemanisan dengan metode scoring), analisis sifat fisik (daya leleh, overrun, dan total padatan terlarut), dan analisis sifat kimia (kadar air, serta pangan, vitamin $\mathrm{C}, \quad \beta$-karoten, dan aktivitas antioksidan).

\section{Rancangan Percobaan}

Penelitian menggunakan pola Rancangan Acak Lengkap (RAL) dengan satu faktor yaitu konsentrasi madu dengan dua kali ulangan sampel dan tiga kali ulangan analisa. Data yang diperoleh pada pengujian fisik, kimia, sensori, dianalisis menggunakan one way ANOVA pada tingkat $\alpha=0,05$. Jika terdapat perbedaan nyata, maka kemudian dilanjutkan dengan uji Duncan Multiple Range Test (DMRT) pada $\alpha=0,05$. Untuk data yang diperoleh dari uji intensitas tingkat kemanisan, dianalisis menggunakan one way ANOVA pada tingkat $\alpha=0,05$. Jika terdapat perbedaan nyata, maka kemudian dilanjutkan dengan uji Tukey.

Tabel 1. Variasi Perbandingan Konsentrasi

Pemanis

\begin{tabular}{ll}
\hline Formula & \multicolumn{1}{c}{ Konsentrasi } \\
\hline Kontrol & $\begin{array}{l}\text { Velva pepaya dengan pemanis 20\% } \\
\text { sukrosa dari total adonan }\end{array}$ \\
F1 & $\begin{array}{l}\text { Velva pepaya dengan pemanis 5\% madu } \\
\text { dari total adonan }\end{array}$ \\
F2 & $\begin{array}{l}\text { Velva pepaya dengan pemanis 10\% madu } \\
\text { dari total adonan }\end{array}$ \\
F3 & $\begin{array}{l}\text { Velva pepaya dengan pemanis 15\% madu } \\
\text { dari total adonan }\end{array}$ \\
\hline
\end{tabular}

\section{HASIL DAN PEMBAHASAN}

\section{Analisis Sensoris Velva Pepaya dengan Pemanis Madu Warna}

Menurut Kartika,.,dkk. (1988), warna merupakan suatu sifat bahan yang dianggap berasal dari penyebaran spektrum sinar. Warna bukan merupakan suatu zat atau benda melainkan suatu sensasi seseorang karena adanya rangsangan dari seberkas energi radiasi yang jatuh ke mata/retina mata.. Menurut Sihombing (2005), zat penyebab warna madu sebagian besar belum diketahui, namun ada yang menduga terdiri dari fraksi yang larut air dan larut lemak. Pada madu berwarna cerah warna disebabkan oleh zat larut air lebih sedikit daripada zat larut lemak. Ada juga yang menduga bahwa warna madu disebabkan oleh berbagai senyawa polifenol, terurutama pada madu berwarna pekat.

Tabel 2 menunjukkan bahwa penggunaan pemanis madu $10 \%$ tidak berbeda nyata terhadap warna velva pepaya kontrol (pemanis sukrosa 20\%). Sedangkan penggunaan pemanis madu 5\% dan $15 \%$ berbeda nyata terhadap warna velva pepaya kontrol. Antar perlakuan menunjukkan penggunaan pemanis madu $5 \%$ berbeda nyata terhadap velva pepaya dengan pemanis madu $10 \%$ tetapi pemanis madu $5 \%$ tidak berbeda nyata terhadap warna velva pepaya $15 \%$ pemanis madu. Secara umum penggunaan 
Tabel 2. Tingkat Kesukaan Panelis Terhadap Velva Pepaya pada Berbagai Perlakuan Formulasi Penggunaan Pemanis

\begin{tabular}{lccccc}
\hline \multirow{2}{*}{ Formulasi* } & \multicolumn{4}{c}{ Parameter Uji **,*** } \\
\cline { 2 - 5 } & Warna & Rasa & Aroma & Tekstur & Overall \\
\hline Kontrol & $3,20^{\mathrm{b}}$ & $3,10^{\mathrm{c}}$ & $2,46^{\mathrm{ab}}$ & $2,90^{\mathrm{a}}$ & $3,03^{\mathrm{c}}$ \\
$\mathrm{F} 1$ & $1,96^{\mathrm{a}}$ & $1,70^{\mathrm{a}}$ & $2,10^{\mathrm{a}}$ & $2,43^{\mathrm{a}}$ & $1,83^{\mathrm{a}}$ \\
$\mathrm{F} 2$ & $3,03^{\mathrm{b}}$ & $2,50^{\mathrm{b}}$ & $2,70^{\mathrm{b}}$ & $2,83^{\mathrm{a}}$ & $2,63^{\mathrm{bc}}$ \\
$\mathrm{F} 3$ & $2,36^{\mathrm{a}}$ & $2,83^{\mathrm{bc}}$ & $2,36^{\mathrm{ab}}$ & $2,80^{\mathrm{a}}$ & $2,56^{\mathrm{b}}$ \\
\hline * : Kontrol: velva pepaya dengan pemanis sukrosa 20\%, F1: velva pepaya dengan pemanis madu 5\%, F2: \\
velva pepaya dengan pemanis masdu 10\%, F3: velva pepaya dengan pemanis madu 15\% \\
**: .Data ditandai dengan huruf yang berbeda pada kolom overall menunjukkan adanya beda nyata pada tiap \\
perlakuan $(\alpha=0,05)$. \\
***: Skor: 4= sangat suka, 3= suka, 2=agak suka, 1= tidak suka
\end{tabular}

pemanis madu menurunkan tingkat kesukaan panelis terhadap parameter warna velva pepaya yang dihasilkan. Tingkat penerimaan panelis terhadap velva pepaya dengan pemanis sukrosa $20 \%$ memiliki tingkat kesukaan panelis tertinggi dibandingkan dengan tiga perlakuan lainnya. Namun, untuk penggunaan pemanis madu terlihat bahwa tingkat kesukaan panelis tertinggi terdapat pada velva pepaya dengan pemanis madu $10 \%$, sedangkan tingkat kesukaan terendah terdapat pada velva pepaya dengan pemanis madu $5 \%$.

\section{Rasa}

Rasa juga merupakan salah satu faktor yang penting yang menyebabkan suatu produk baru dapat diterima atau tidak oleh konsumen. Penilaian parameter rasa bersifat relatif bersifat relatif yang artinya enak menurut orang yang satu belum tentu dinilai enak juga menurut orang lain..

Berdasarkan Tabel 2 menunjukkan bahwa pemanis madu 5\% dan $10 \%$ berbeda nyata terhadap rasa velva pepaya kontrol. Sedangkan pemanis madu $15 \%$ tidak berbeda nyata terhadap rasa velva pepaya kontrol. Untuk tiga perlakuan, penggunaan pemanis madu $5 \%$ berbeda nyata dengan rasa velva pepaya dengan pemanis madu $10 \%$ dan $15 \%$. Sedangkan penggunaan pemanis madu $10 \%$ tidak berbeda nyata dengan rasa velva pepaya dengan pemanis madu $15 \%$. Secara umum penggunaan pemanis madu menurunkan tingkat kesukaan konsumen terhadap parameter rasa velva pepaya yang dihasilkan. Rasa velva pepaya yang paling disukai oleh panelis adalah rasa velva pepaya pemanis sukrosa $20 \%$ dan rasa velva pepaya pemanis madu 15\%. Madu yang ditambahkan memberikan pengaruh terhadap velva pepaya karena madu memiliki rasa manis yang khas. Rasa khas dari madu bercampur dengan rasa dari buah pepaya yang digunakan, namun rasa buah pepaya yang digunakan lebih mendominasi rasa yang terbentuk pada velva pepaya.

\section{Aroma}

Menurut Winarno (2002), aroma adalah salah satu parameter identifikasi flavor yang paling mudah dan paling sering dilakukan. Bahan pangan dapat menghasilkan aroma jika senyawa yang menghasilkan bau dapat menguap (Winarno,2008). Berdasarkan Tabel 2 pemanis madu 5\%, $10 \%$, dan $15 \%$ tidak berbeda nyata terhadap aroma velva pepaya kontrol (pemanis sukrosa 20\%). Sedangkan untuk antar perlakuan, aroma velva pepaya dengan pemanis madu $5 \%$ berbeda nyata dengan aroma velva pepaya pemanis madu $10 \%$, tetapi tidak berbeda nyata dengan aroma velva pepaya pemanis madu $15 \%$. Sedangkan pemanis madu $10 \%$ tidak berbeda nyata dengan aroma velva pepaya pemanis $15 \%$. Secara umum juga terlihat bahwa panelis paling menyukai aroma velva pepaya dengan pemanis madu $10 \%$. Aroma madu yang khas disebabkan oleh kandungan zat organiknya yang mudah menguap (volatil).

\section{Tekstur}

Menurut Arbuckle (1986), tekstur frozen dessert berperan penting dalam menentukan tingkat penerimaan konsumen. Tekstur produk-produk es krim yang disukai adalah tekstur yang lembut, halus dan ukuran 
Tabel 3. Tingkat Kemanisan Velva Pepaya pada Berbagai Perlakuan Formulasi Konsentrasi Pemanis Madu

\begin{tabular}{cc}
\hline Formulasi $^{*}$ & $\begin{array}{c}\text { Tingkat } \\
\text { Kemanisan****** }\end{array}$ \\
\hline F1 & $6,00^{\mathrm{c}}$ \\
F2 & $4,53^{\mathrm{b}}$ \\
F3 & $3,23^{\mathrm{a}}$
\end{tabular}

* : F1: velva pepaya dengan pemanis madu 5\%, F2: velva pepaya dengan pemanis masdu $10 \%$, F3: velva pepaya dengan pemanis madu $15 \%$

**: .Data ditandai dengan huruf yang berbeda pada kolom overall menunjukkan adanya beda nyata pada tiap perlakuan $(\alpha=0,05)$.

***: Skor: 1: sedikit lebih manis dari kontrol

2: cukup lebih manis dari kontrol

3: banyak lebih manis dari kontrol

4: sama manis dengan kontrol

5: sedikit kurang manis dari kontrol

6: cukup kurang manis dari kontrol

7: banyak kurang manis dari control

partikel padatan sangat kecil sehingga tidak terdeteksi di dalam mulut. Hasil analisis tingkat kesukaan terhadap tekstur velva pepaya dapat dilihat pada Tabel 2 .

Pada Tabel 2 dapat dilihat bahwa tekstur velva pepaya dengan pemanis madu tidak berbeda nyata dengan tekstur velva pepaya dengan pemanis sukrosa $20 \%$, dan konsentrasi pemanis madu tidak mempengaruhi tekstur velva pepaya yang dihasilkan. Secara umum penggunaan pemanis madu menurunkan tingkat kesukaan panelis terhadap tekstur velva pepaya yang dihasilkan. Tekstur velva dapat dihubungkan dengan mutu pelelehan (daya leleh). Tekstur produk yang tidak mudah meleleh umumnya lebih disukai oleh konsumen. Berdasarkan Tabel 2. dapat dikatakan bahwa panelis lebih menyukai tekstur velva pepaya dengan pemanis madu $10 \%$. Hasil tersebut berbeda dengan hasil uji fisik velva pepaya (daya leleh) dimana semakin besar konsentrasi penambahan madu yang ditambahkan maka semakin lambat kemampuan meleleh velva pepaya.

\section{Overall}

Uji kesukaan keseluruhan merupakan penilaian terhadap semua faktor mutu yang meliputi warna, rasa, aroma, dan tekstur yang dimaksud untuk mengetahui tingkat kesukaan panelis terhadap produk velva pepaya dengan penambahan madu. Dari hasil analisa pada Tabel 2 bahwa secara overall penerimaan panelis terhadap velva pepaya dengan pemanis madu $5 \%$ dan $15 \%$ berbeda nyata jika dibandingkan dengan overall velva pepaya kontrol. Jika dibandingkan antar perlakuan overall velva pepaya dengan pemanis madu $5 \%$ berbeda nyata terhadap overall velva pepaya pemanis madu $10 \%$ dan $15 \%$, sedangkan overall velva pepaya dengan pemanis madu $10 \%$ tidak berbeda nyata dengan overall velva pepaya pemanis madu $15 \%$. Secara umum terlihat bahwa penggunaan pemanis madu menurunkan tingkat penerimaan panelis terhadap parameter overall velva pepaya yang dihasilkan. Tingkat penerimaan tertinggi ada pada velva pepaya pemanis sukrosa 20\%. Secara keseluruhan velva pepaya pemanis sukrosa $20 \%$ diterima oleh konsumen karena memiliki cita rasa khas buah pepaya yang masih dipertahankan.

\section{Uji Intensitas (Uji Skoring)}

Pada penelitian ini juga dilakukan uji pembedaan (intensitas sifat sensori dengan metode skoring) untuk mengetahui perbedaan tingkat kemanisan velva pepaya. Uji yang dilakukan dengan cara membandingkan tingkat kemanisan velva pepaya dengan pemanis sukrosa $20 \%$ dibandingkan dengan velva pepaya dengan berbagai konsentrasi penambahan madu. Setelah dilakukan penilaian selanjutnya hasil yang diperoleh dilanjutkan menggunakan uji lanjutan yaitu uji Tukey (Bambang dkk, 1988).Tingkat kemanisan velva pepaya dengan pemanis madu 5\%, 10\%, dan 15\% memiliki tingkat kemanisan yang berbeda nyata. Velva pepaya dengan pemanis madu 5\% memiliki tingkat kemanisan lebih rendah dari kontrol. Velva pepaya dengan pemanis madu $10 \%$ memiliki tingkat kemanisan sama dengan kontrol. Sedangkan velva pepaya dengan pemanis madu $15 \%$ memiliki tingkat kemanisan lebih tinggi dari kontrol. Velva pepaya dengan pemanis madu memiliki tingkat kemanisan yang lebih tinggi dibandingkan velva pepaya dengan pemanis sukrosa. 


\section{Sifat Fisik Velva Pepaya Dengan Penambahan Madu \\ Daya Leleh}

Menurut Bodyfelt (1988), es krim yang berkualitas baik menunjukkan resistensi yang tinggi terhadap pelelehan. Mutu pelelehan dinilai dengan merasakannya di mulut, yaitu apakah produk tersebut dapat dengan mudah meleleh dan memberi kesan "meluncur" di dalam mulut atau kaku dan sulit meleleh. Daya pelelehan merupakan salah satu parameter mutu yang penting dalam industri makanan beku pencuci mulut. Daya leleh identik dengan waktu yang dibutuhkan es krim untuk meleleh sempurna pada suhu ruang.

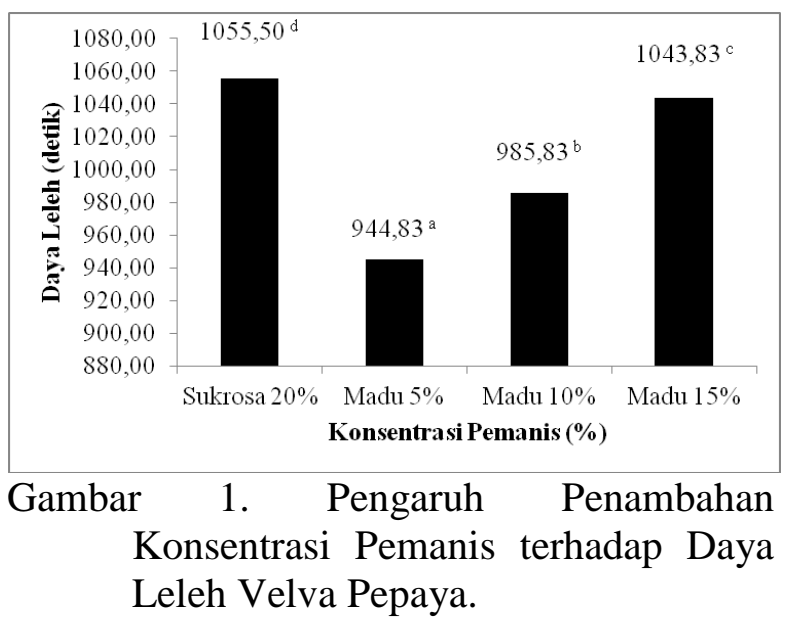

Hasil analisis menunjukkan bahwa penambahan konsentrasi madu memberikan pengaruh nyata terhadap daya leleh velva pepaya. Hasil pengukuran daya leleh velva pepaya berkisar antara 15 menit 34 detik hingga 17 menit 37 detik. Daya leleh tertinggi adalah velva pepaya dengan pemanis sukrosa $20 \%$ yaitu 1055,50 detik (17 menit 59 detik) dan daya leleh terendah adalah velva pepaya dengan pemanis madu 5\% yaitu 944,83 detik (15 menit 14 detik). Berdasarkan hasil yang diperoleh terlihat bahwa semakin tinggi konsentrasi penambahan madu yang diberikan maka daya leleh velva pepaya semakin rendah / semakin lambat. Semakin tinggi konsentrasi madu yang ditambahkan maka semakin tinggi kandungan gula yang terdapat pada adonan velva.

\section{Overrun}

Overrun dapat diartikan sebagai pengembangan volume es krim terhadap volume adonan mula-mula karena adanya udara yang terperangkap dalam es. Overrun dengan nilai tertinggi terdapat pada velva pepaya dengan penambahan konsentrasi madu 5\%. Sedangkan nilai overrun terendah terdapat pada velva pepaya tanpa penambahan madu.

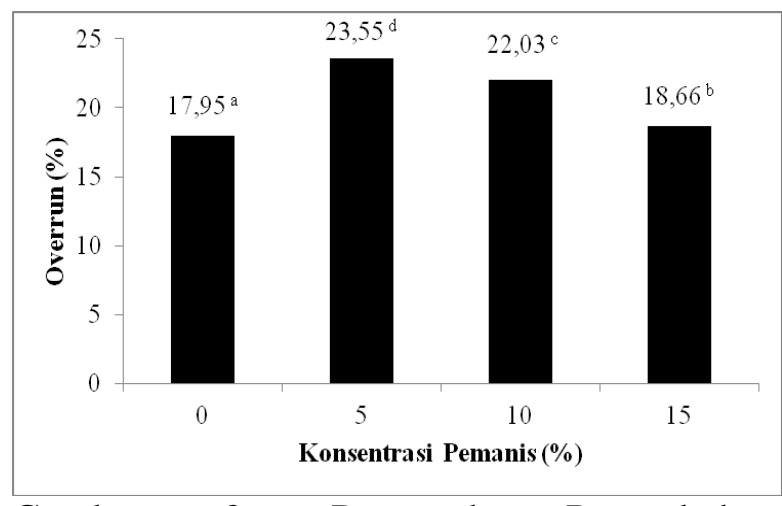

Gambar 2. Pengaruh Penambahan Konsentrasi Pemanis terhadap Overrun Velva Pepaya.

Dari hasil yang diperoleh juga terlihat bahwa semakin tinggi konsentrasi pemanis madu yang ditambahkan ke dalam adonan maka nilai overrun velva pepaya yang dihasilkan semakin rendah. Madu memiliki sifat fisik yang kental. Kekentalan madu menunjukkan madu tersebut madu tersebut memiliki viskositas yang tinggi. Semakin tinggi konsentrasi madu yang ditambahkan maka semakin kental adonan velva pepaya yang dihasilkan.

\section{Total Padatan Terlarut (TPT)}

Total padatan terlarut (total soluble solid) umunya dinyatakan dalam ${ }^{\circ}$ Brix gula sukrosa. Padatan terlarut yang terkandung dalam suatu produk mempunyai sifat fisik dan kimia produk tersebut diantaranya titik beku, titik didih, viskositas, dan kelarutannya.Total padatan terlarut velva pepaya dengan penambahan madu terlihat bahwa velva pepaya dengan pemanis sukrosa $20 \%$ (kontrol) memiliki total padatan terlarut sebesar $19,33^{\circ}$ Brix, velva pepaya dengan konsentrasi pemanis madu $5 \%$ (F1) sebesar $6,00{ }^{\circ}$ Brix, velva pepaya dengan konsentrasi 
pemanis madu $10 \%(\mathrm{~F} 2)$ sebesar $10,17^{\circ}$ Brix, dan velva pepaya dengan konsentrasi pemanis madu $15 \%$ (F3) sebesar $11,00{ }^{\circ}$ Brix. Hasil tersebut terlihat bahwa semakin tinggi konsentrasi penambahan madu akan meningkatkan total padatan terlarut velva pepaya secara nyata. Semakin tinggi konsentrasi penambahan madu dapat meningkatkan total padatan terlarut velva pepaya.

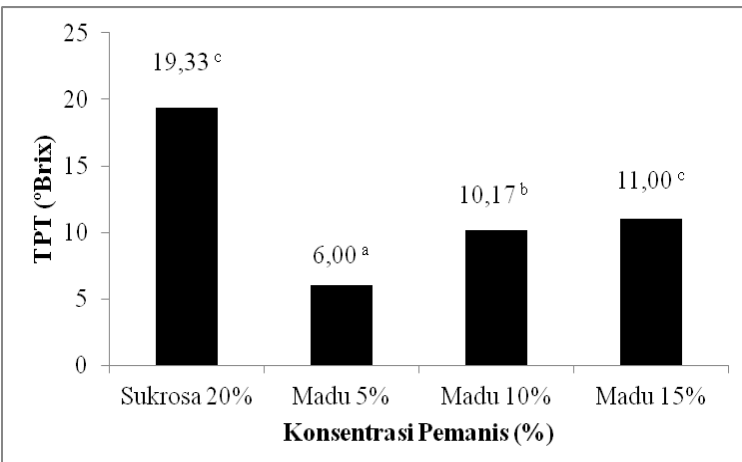

Gambar 3. Pengaruh Penambahan Konsentrasi Pemanis terhadapTotal Padatan Terlarut Velva Pepaya

\section{Sifat Kimia Velva Pepaya Dengan Penambahan Madu}

Kadar Air

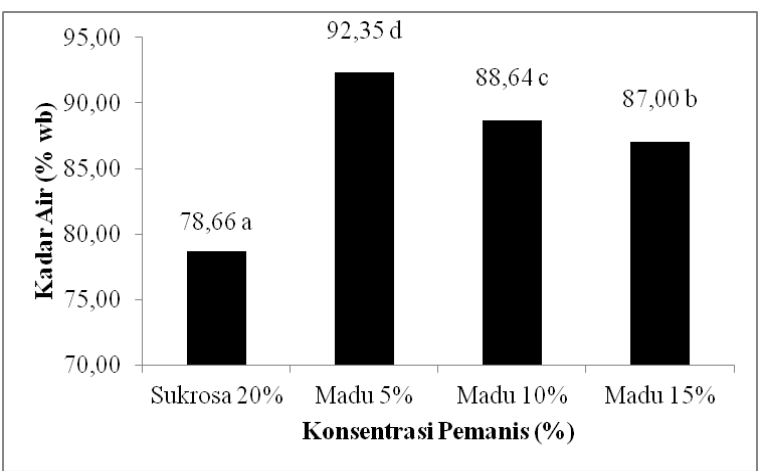

Gambar 4. Pengaruh Penambahan Konsentrasi Pemanis terhadap Kadar Air Velva Pepaya

Hasil analisis terhadap kadar air velva pepaya dengan pemanis madu menunjukkan bahwa konsentrasi pemanis madu yang ditambahkan terhadap velva pepaya berpengaruh nyata meningkatkan kadar air velva pepaya. Semakin besar konsentrasi pemanis madu yang ditambahkan ke dalam adonan velva pepaya maka kadar air yang dihasilkan semakin rendah. Kadar air velva pepaya dengan pemanis sukrosa $20 \%$ (kontrol) sebesar 78,66\%, velva pepaya dengan pemanis madu 5\% (F1) sebesar $92,35 \%$, velva pepaya dengan pemanis madu $10 \%$ (F2) sebesar 88,64\%, dan kadar air velva pepaya dengan pemanis madu $15 \%(\mathrm{~F} 3)$ yaitu sebesar $87,00 \%$.

\section{Serat Pangan}

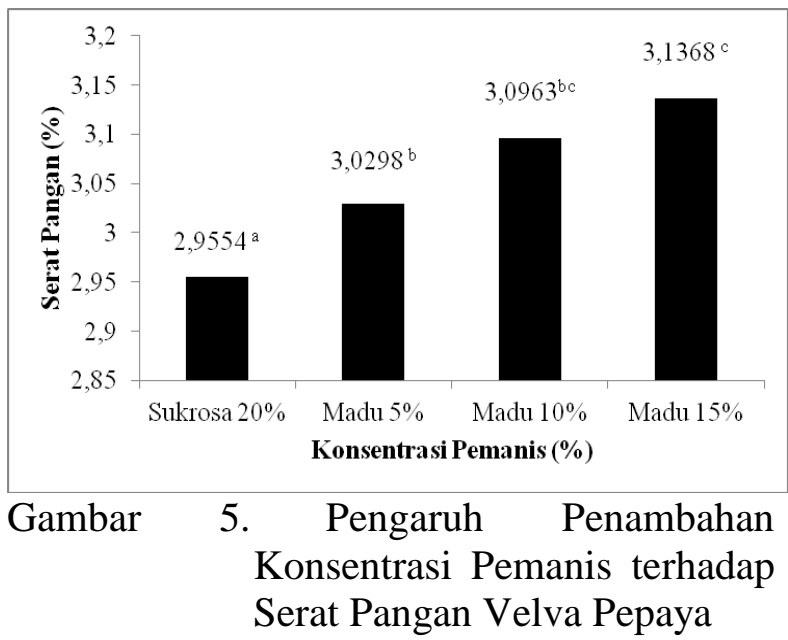

Penggunaan madu sebagai pemanis meningkatkan kandungan serat pangan velva pepaya yang dihasilkan. Semakin tinggi konsentrasi madu yang ditambahkan akan meningkatkan serat pangan pada velva pepaya. Velva pepaya dengan pemanis sukrosa 20\% (kontrol) memiliki serat pangan sebesar 2,9554 \%, velva pepaya dengan konsentrasi pemanis madu 5\% (F1) sebesar $3,0298 \%$, velva pepaya dengan konsentrasi pemanis madu 10\% (F2) sebesar 3,0963\%, dan velva pepaya dengan konsentrasi pemanis madu $15 \%$ (F3) sebesar 3,1368\%. Hasil analisis sidik ragam juga menunjukkan bahwa penambahan konsentrasi madu berpengaruh nyata terhadap kadar serat pangan velva pepaya. Kandungan serat pangan velva pepaya dengan pemanis sukrosa $20 \%$ lebih rendah dibandingkan dengan kandungan serat pangan pada velva pepaya dengan pemanis madu 5\%, 10\%, dan $15 \%$.

\section{Vitamin C}

Semakin tinggi konsentrasi pemanis madu yang diberikan maka kadar vitamin $\mathrm{C}$ velva pepaya semakin meningkat. Velva pepaya dengan pemanis sukrosa $20 \%$ (kontrol) memiliki kadar vitamin $\mathrm{C}$ terendah yaitu sebesar 26,40 mg/100g, sedangkan 
kadar vitamin $\mathrm{C}$ velva pepaya dengan pemanis madu 5\% (F1) dan 10\% (F2) sebesar 28,60mg/100g dan 37,40mg/100g. Kadar vitamin $\mathrm{C}$ tertinggi dihasilkan pada velva pepaya dengan pemanis madu $15 \%$ (F3) yaitu sebesar 46,20mg/100g.

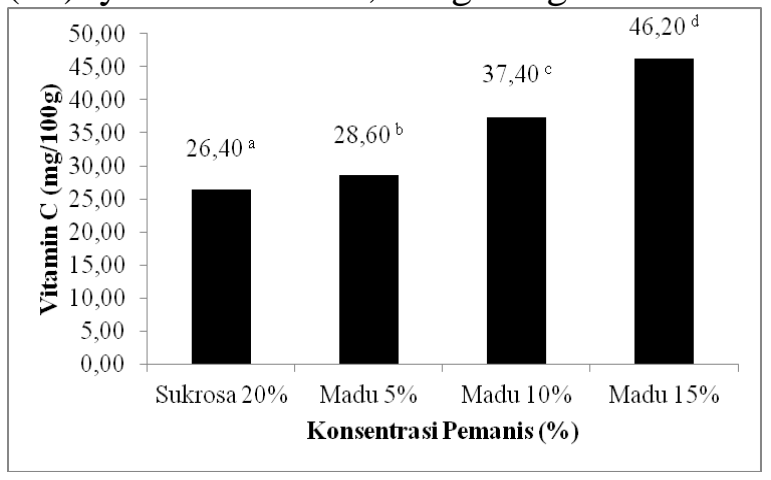

Gambar 6. Pengaruh Penambahan Konsentrasi Pemanis terhadap Vitamin C Velva Pepaya

\section{$\beta$-Karoten}

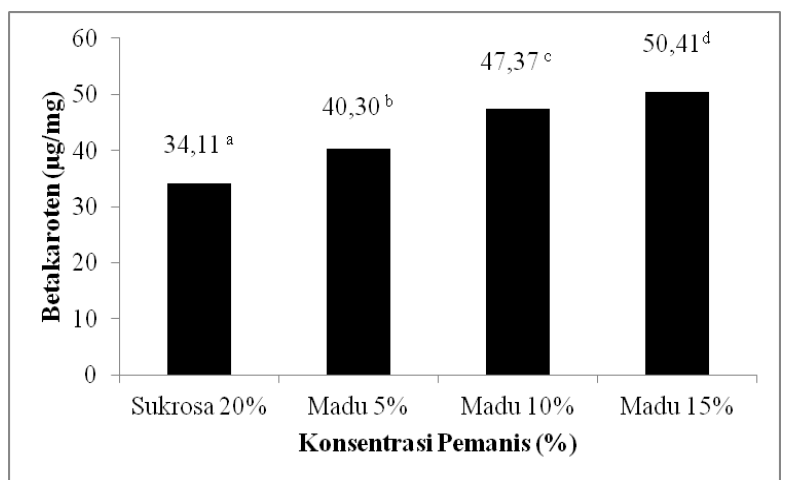
Gambar 7. Pengaruh Penambahan Konsentrasi Madu terhadap Betakaroten Velva Pepaya.

Kandungan $\beta$-karoten velva pepaya dengan pemanis sukrosa lebih rendah jika dibandingkan dengan $\beta$-karoten velva pepaya dengan pemanis madu, hal tersebut dapat disebabkan oleh tidak adanya kandungan $\beta$ karoten di dalam sukrosa sehingga kandungan $\beta$-karoten yang terdapat pada velva pepaya dengan pemanis sukrosa hanya berasal dari buah pepaya yang digunakan. Velva pepaya dengan pemanis sukrosa (kontrol) memiliki kadar $\beta$-karoten sebesar $34,11 \mu \mathrm{g} / \mathrm{mg}$, velva pepaya dengan pemanis madu 5\% (F1) sebesar 40,30 $\mathrm{g} / \mathrm{mg}$, velva pepaya dengan pemanis madu $10 \%$ (F2) sebesar $47,37 \mu \mathrm{g} / \mathrm{mg}$ dan velva pepaya dengan pemanis madu $15 \%$ (F3) sebesar 50,41 $\mu \mathrm{g} / \mathrm{mg}$. Hasil analisis uji sidik ragam juga menunjukkan bahwa penambahan konsentrasi madu berpengaruh nyata terhadap peningkatan kadar $\beta$-karoten pada velva pepaya.

\section{Aktivitas Antioksidan}

Aktivitas antioksidan velva pepaya dengan penambahan madu terlihat bahwa velva pepaya dengan pemanis sukrosa $20 \%$ (kontrol) memiliki kadar antioksidan sebesar $74,58 \%$, velva pepaya dengan konsentrasi pemanis madu 5\% (F1) sebesar 80,79\%, velva pepaya dengan konsentrasi pemanis madu $10 \%$ (F2) sebesar $85,92 \%$, dan velva pepaya dengan konsentrasi pemanis madu $15 \%$ (F3) sebesar 88,85\%. Dari hasil tersebut terlihat bahwa semakin tinggi konsentrasi penambahan madu maka akan meningkatkan kadar antioksidan velva papaya.

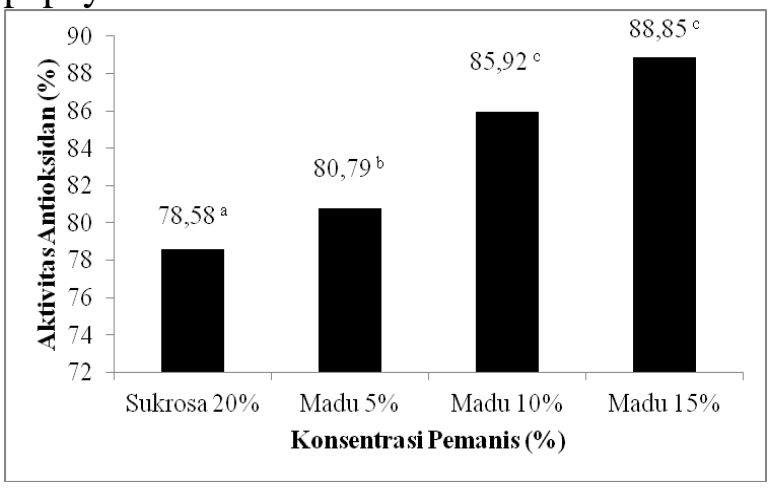

Gambar 8. Pengaruh Penambahan Konsentrasi Pemanis terhadap Antioksidan Velva Pepaya

\section{KESIMPULAN}

1. Penggunaan pemanis madu memberikan pengaruh terhadap karakteristik kimia velva pepaya berupa penurunan kadar air (dengan kisaran 92,35 - 87,00\%), terjadi pula peningkatan serat pangan $(2,9554$ $3,0298 \%)$, vitamin C $(26,40-46,20$ $\mathrm{mg} / 100 \mathrm{~g})$, kadar $\beta$-karoten $(34,11-50,41$ $\mu \mathrm{g} / \mathrm{mg})$, antioksidan $(78,58-88,85 \%)$, dan total padatan terlarut $(6,00$ $11,00^{\circ}$ brix). Penggunaan pemanis madu juga memberikan pengaruh terhadap karakteristik fisik velva pepaya berupa peningkatan daya leleh $(944,83$ - 1043,83 
detik), dan penurunan overrun $(23,55$ $18,66 \%$ ).

2. Karakteristik sensoris velva pepaya dengan penggunaan pemanis madu, diketahui bahwa pemanis madu $5-15 \%$ berpengaruh nyata terhadap skor penilaian kesukaan panelis pada parameter warna, rasa, dan overrall velva pepaya, dan tidak memberikan pengaruh nyata pada parameter tekstur dan aroma velva pepaya yang dihasilkan. Uji intensitas (uji skoring) diketahui bahwa velva pepaya dengan pemanis madu $5 \%$ memiliki tingkat kemanisan lebih rendah dari kontrol, velva pepaya dengan pemanis madu $10 \%$ memiliki tingkat kemanisan sama dengan kontrol, dan velva pepaya dengan pemanis madu $15 \%$ memilik tingkat kemanisan lebih tinggi dari kontrol.

\section{DAFTAR PUSTAKA}

Arbuckle, W.S. 1986. Ice Cream. The AVI

Pub. Company, Inc., Wesport,

Conneticut

Bodyfelt, F. W., J. Tobias., dan G. Trout. 1988. The Sensory Evalution of Diary Product. AVI Publishing Company, Wesport, Connecticut.

Eswandari, Novie. H. 2012. Pengaruh Kombinasi Bahan Penstabil CMC dan Gum Arab Terhadap Mutu Velva Pepaya (Carica papaya L.) Pada Tingkat Kematangan Yang Berbeda. Skripsi Jurusan Teknologi Hasil Pertanian, Fakultas Pertanian, Universitas Sebelas Maret.

Ihsan, F., dan Anang Wahyudi. 2010. Teknik Analisis Kadar Sukrosa Pada Buah Pepaya. Buletin Teknik Pertanian Vol. 15, No. 1, 2010: 10-12.

Kartika, Bambang., Pudji, H,.dan Wahyu, S. 1988. Pedoman Uji Inderawi Bahan Pangan. UGM Press. Yogyakarta
Parwata, O. I. M., K. Ratnayani., dan Ana Listya. 2010. Aktivitas Antiradikal Bebas Serta Kadar Beta Karoten Pada Madu Randu (Ceiba pentandra) dan Madu Kelengkeng (Nephelium longata L.) Jurnal Kimia 4 (1), Januari 2010: 54-62.

Putriwindani, R.M. 2011. Analisis Proses Keputusan Pembelian Dan Kepuasan Konsumen Madu Pramuka Di PT. Madu Pramuka Serta Implikasinya Terhadap Bauran Pemasaran. Skripsi Departemen Agribisnis, Fakultas Ekonomi Dan Manajemen, Institut Pertanian Bogor.

Rahayuningsih. 1998. Ekstraksi dan Stabilitas Warna Ubi Jalar Ungu (Ipomea batatas L.,) Sebagai Pewarna Alami. Jurnal Teknik Jilid 22, No.1 September 2008. Surabaya.

Rukmana, Rahmat. 2005. Pepaya, Budidaya dan Pasca Panen. Kanisius. Yogyakarta.

Safaryani, N., Sri Haryati, dan Endah. D.H. 2007. Pengaruh Suhu dan Lama Penyimpanan Terhadap Penurunan Kadar Vitamin C Brokoli (Brassica oleracea L). Buletin Anatomi dan Fisiologi Vo.XV, No.2. UNDIP. Semarang.

Sakri, Faisal. M. 2012. Madu dan Khasiatnya. Diandra Pustaka. Yogyakarta.

Silalahi. Jansen. 2006. Makanan Fungsional. Kanisius. Yogyakarta.

Situmorang, T.K. 2010. Pengaruh Pemberian Jus Pepaya (Carica papaya L.) Sebagai Hepatoprotektor Terhadap Hepar Mencit Yang Dipapar Parasetamol. Skripsi Fakultas Kedokteran. Universitas Sebelas Maret.

Winarno, F. G. 2002. Kimia Pangan dan Gizi. PT. Gramedia Pustaka Utama. Jakarta 